\title{
Coral Reef Populations in the Caribbean: Is There a Case for Better Protection against Climate Change?
}

\author{
Michael James C. Crabbe \\ Institute for Biomedical and Environmental Science and Technology, Faculty of Creative Arts, Technologies and Science, \\ University of Bedfordshire, Luton, UK \\ Email: james.crabbe@beds.ac.uk
}

Received November 20, 2012; revised December 26, 2012; accepted January 9, 2013

Copyright (C) 2013 Michael James C. Crabbe. This is an open access article distributed under the Creative Commons Attribution License, which permits unrestricted use, distribution, and reproduction in any medium, provided the original work is properly cited.

\begin{abstract}
Knowledge of factors that are important in coral reef growth help us to understand how reef ecosystems react following major environmental disturbances due to climate change and other anthropogenic effects. This study shows that despite a range of anthropogenic stressors, corals on the fringing reefs south of Kingston harbour, as well as corals on fringing reefs on the north coast of Jamaica near Discovery Bay can survive and grow. Skewness values for Sidastrea siderea and Porites astreoides were positive $(0.85$ - 1.64) for all sites, implying more small colonies than large colonies. Coral growth rates are part of a demographic approach to monitoring coral reef health in times of climate change, and linear extension rates $\left(\mathrm{mm} \cdot \mathrm{yr}^{-1}\right)$ of Acropora palmata branching corals at Dairy Bull, Rio Bueno, and Pear Tree Bottom on the north coast of Jamaica were c. 50 - $90 \mathrm{~mm} \cdot$ year $^{-1}$ from 2005-2012. The range of small-scale rugosities at the Port Royal cay sites studied was lower than that at the Discovery Bay sites; for example Rio Bueno was $1.05 \pm 0.15$ and Dairy Bull the most rugose at $2.3 \pm 0.16$. Diary Bull reef has for several years been the fringing reef with the most coral cover, with a benthic community similar to that of the 1970s. We discuss whether Jamaica can learn from methods used in other Caribbean countries to better protect its coral reefs against climate change. Establishing and maintaining fully-protected marine parks in Jamaica and elsewhere in the Caribbean is one tool to help the future of the fishing industry in developing countries. Developing MPAs as part of an overall climate change policy for a country may be the best way of integrating climate change into MPA planning, management, and evaluation.
\end{abstract}

Keywords: Demographics; Belize; Jamaica; MPAs; GDP; Hurricanes; Fishing; Bleaching; Climate Change; Global Warming

\section{Introduction}

Coral reefs throughout the world are under severe challenges from environmental factors including overfishing, destructive fishing practices, coral bleaching, ocean acidification, sea-level rise, algal blooms, agricultural run-off, coastal and resort development, marine pollution, increasing coral diseases, invasive species, ocean acidification, rising sea level, changing circulation patterns, increasing severity of storms, changing freshwater influxes and hurricane/cyclone damage (e.g. [1-4]). The fringing reefs around Jamaica constitute one of the best documented areas of reef decline in the Caribbean, where significant loss of corals and macroalgal domination has been due to hurricanes [5-7], overfishing [8,9], die-off of the long-spined sea urchin Diadema antillarum in 19831984 [10], and coral disease [11]. Nutrient enrichment does not appear to have been a causal factor in the de- velopment of these reef macroalgal communities [12].

Warming ocean (sea surface) temperatures due to climate change are considered to be an important cause of the degradation of the world's coral reefs. Marine protected areas (MPAs) have been proposed as one tool to increase coral reef ecosystem resistance and resilience (i.e. recovery) to the negative effects of climate change. However, few studies have evaluated their efficacy in achieving these goals.

While healthy reefs usually have high numbers of coral recruits and juvenile corals, degraded systems typically have limited numbers of young colonies $[13,14]$. To manage coral reefs it is important to have an understanding of coral population demography-structure and dynamics. Ideally, this involves the quantification of numbers of individual colonies of different size classes-the population structure-through time, in addition to quantifying coral growth rates, recruitment and survival. 
Knowledge of coral population structure helps in understanding how reefs react following disturbance, and provides us with an early warning system for predicting future reef health.

Here we studied recent non-branching coral population structure at sites near Discovery Bay on the north coast of Jamaica, and at sites near Kingston Harbour, on the south coast of Jamaica.

Kingston harbour is a major trans-shipment post for the Caribbean, and in 2002 a major ship channel (East Channel) was constructed by Rackham's Cay, near Port Royal to accommodate vessels with draft of up to 14.5 metres and beams of 42 metres [15]. In addition, the harbour is highly polluted, mostly due to an excessive input of sewage [16-19]. This study shows that despite these and other environmental stressors, corals can survive on the fringing reefs south of the harbour.

MPAs provide in-situ-based management of marine ecosystems through various degrees and methods of protective actions. As impacts of climate change strengthen they may exacerbate effects of existing stressors and require new or modified management approaches; for example MPA networks may be an improvement over individual MPAs in addressing multiple threats to the marine environment. We discuss whether Jamaica can learn from methods used in other Caribbean countries to better protect its coral reefs in times of climate change.

\section{Materials and Methods}

\subsection{Reef Sites}

GPS coordinates were determined using a hand-held receiver (Garmin Ltd.).

In Discovery Bay, Jamaica, surface areas of non-branching corals between 5 - $9 \mathrm{~m}$ depth, were measured using SCUBA at four sites [Rio Bueno $\left(18^{\circ} 28.805^{\prime} \mathrm{N} ; 77^{\circ} 21.625^{\prime}\right.$ W), M1 (18 $\left.28.337^{\prime} \mathrm{N} ; 77^{\circ} 24.525^{\prime} \mathrm{W}\right)$, Dancing Ladies $\left(18^{\circ} 28.369^{\prime} \mathrm{N} ; 77^{\circ} 24.802^{\prime} \mathrm{W}\right)$, Dairy Bull $\left(18^{\circ} 28.083^{\prime} \mathrm{N}\right.$; $\left.77^{\circ} 23.302^{\prime} \mathrm{W}\right)$ and Pear Tree Bottom $\left(18^{\circ} 27.829^{\prime} \mathrm{N}\right.$; $\left.\left.77^{\circ} 21.403^{\prime} \mathrm{W}\right)\right]$ along the fringing reefs surrounding Discovery Bay, Jamaica. Overall, surface areas of 209 nonbranching corals were measured in 2012 (Table 1(a)).

This work was conducted at Discovery Bay during August 8-August 10 in 2012.

For sites near Port Royal, Jamaica, surface areas of non-branching corals were measured using SCUBA at seven sites south of Port Royal. Six of these were fringing reefs around the cays South of Port Royal: SE Barrier Cay $\left(17^{\circ} 53.714^{\prime} \mathrm{N}, 76^{\circ} 48.226^{\prime} \mathrm{W}\right)$; Lime Cay $\left(17^{\circ} 54.948^{\prime} \mathrm{N}\right.$, $\left.76^{\circ} 49.134^{\prime} \mathrm{W}\right)$; Gun Cay $\left(17^{\circ} 55.9011^{\prime} \mathrm{N}, 76^{\circ} 50.141^{\prime} \mathrm{W}\right)$; Drunkenman's Cay $\left(17^{\circ} 54.128^{\prime} \mathrm{N}, 76^{\circ} 50.736^{\prime} \mathrm{W}\right)$, the face of the ship channel made in 2002 along the reef of Rackham's Cay $\left(17^{\circ} 55.571^{\prime} \mathrm{N}, 76^{\circ} 50.307^{\prime} \mathrm{W}\right)$ and Maiden Cay $\left(17^{\circ} 54.506^{\prime} \mathrm{N}, 76^{\circ} 48.728^{\prime} \mathrm{W}\right)$; a seventh site was the wreck of the ship Edina, south of the barrier reef $\left(17^{\circ} 49.525^{\prime} \mathrm{N}, 76^{\circ} 50.723^{\prime} \mathrm{W}\right)$. Depth of samples at six of the sites was between $5-12 \mathrm{~m}$, at the Edina wreck it was between $22-28 \mathrm{~m}$.

Overall, surface areas of 347 non-branching corals were measured in 2010 (Table 1(b)) and of 451 nonbranching corals in 2012 (Table 1(c)).

This work was conducted in April 14-16 in 2010 and July 30-August 2 in 2012. SE Barrier Cay was only studied in 2010, owing to time limitations caused by tropical storm Ernesto in 2012.

\subsection{Sampling}

Details of data sampling have been described for North Jamaica and South Jamaica [6,20]. In summary, corals $2 \mathrm{~m}$ either side of transect lines were photographed for archive information, and surface areas measured with flexible tape as described previously using SCUBA. For non-branching corals, this was done by measuring the widest diameter of the coral and the diameter at $90^{\circ}$ to that.

In all cases except that of the Edina wreck near Port Royal, which was $22-28 \mathrm{~m}$, depth of samples was between $5-12 \mathrm{~m}$, to minimise variation in growth rates due to depth [21]. To increase accuracy, surface areas rather than diameters of live non-branching corals were measured [6]. Sampling was over as wide a range of sizes as possible. Colonies that were close together $(<50 \mathrm{~mm})$ or touching were avoided to minimise age discontinuities through fission and altered growth rates [22,23]. In this study we ignored Montastrea annularis colonies, because their surface area does not reflect their age [22], and because hurricanes can increase their asexual reproduction through physical damage [23].

Computer digital image analysis for coral linear extension rates was undertaken using the UTHSCSA (University of Texas Health Science Center, San Antonio, Texas, USA) Image Tool software (see [6]). One-factor ANOVA was used; \pm error values represent standard errors of the data.

Skewness [24] (sk) was used to estimate the distribution of small and large colonies in the coral populations. Negative skewness implies more large colonies than small colonies, while conversely positive skewness implies more small colonies than large colonies.

\subsection{Rugosity}

Rugosity $(R)$ was determined according to the formula:

$$
R=S r / S g
$$

where $S r=$ real surface distance between two points, and $S g=$ straight line geometric distance between two points. This was calculated over a $20 \mathrm{~m}$ distance, performed in 
Table 1. Coral species and numbers studied at sites around Port Royal in 2010 and 2012, and around Discovery Bay in 2012. (a) Corals at sites around Discovery Bay in 2012; (b) Corals at sites around Port Royal in 2010; (c) Corals at sites around Port Royal in 2012.

\begin{tabular}{|c|c|c|c|c|c|}
\hline \multicolumn{6}{|c|}{2012} \\
\hline Species & Dairy Bull & M1 & Pear Tree & Rio Bueno & Total \\
\hline ss & 37 & 12 & 2 & 7 & 58 \\
\hline pa & 19 & 10 & 12 & 9 & 50 \\
\hline mean mean & 6 & 25 & 4 & 1 & 36 \\
\hline dip strig & 2 & & & 8 & 10 \\
\hline ag ag & 5 & & 2 & 3 & 10 \\
\hline mont cav & 6 & & & 2 & 8 \\
\hline dip laby & 4 & 4 & 3 & & 11 \\
\hline eusmilia & 2 & & 1 & & 3 \\
\hline manicina & & & & & 0 \\
\hline muss ang & & & & & 0 \\
\hline mycetophyllia & 10 & & & & 10 \\
\hline col natans & 4 & 5 & 1 & 3 & 13 \\
\hline Total & 95 & 56 & 25 & 33 & 209 \\
\hline
\end{tabular}

\begin{tabular}{|c|c|c|c|c|c|c|c|c|}
\hline \multicolumn{9}{|c|}{2010} \\
\hline Species & Rackhams & Edina wreck & Drunkenmans & SE barrier & Maiden & Lime & Gun & Total \\
\hline ss & 78 & 20 & 12 & 21 & 5 & 23 & 10 & 169 \\
\hline pa & 10 & 6 & 28 & 15 & & 2 & 7 & 68 \\
\hline mean mean & 9 & 3 & 6 & 4 & 3 & 4 & 1 & 30 \\
\hline dip streg & 1 & 16 & 8 & 12 & & 4 & & 41 \\
\hline ag ag & & 1 & & & & & & 1 \\
\hline mont cav & & 8 & 4 & 2 & & 2 & 10 & 26 \\
\hline dip laby & & & 2 & 2 & 2 & 3 & 1 & 10 \\
\hline eusmilia & & & & & & 1 & & 1 \\
\hline col natans & & & & & & & 1 & 1 \\
\hline Total & 98 & 54 & 60 & 56 & 10 & 39 & 30 & 347 \\
\hline
\end{tabular}

(c)

\begin{tabular}{|c|c|c|c|c|c|c|c|}
\hline \multicolumn{8}{|c|}{2012} \\
\hline Species & Rackhams & Edina wreck & Drunkenmans & Maiden & Lime & Gun & Total \\
\hline ss & 35 & 17 & 22 & 42 & 43 & 33 & 192 \\
\hline pa & 6 & 9 & 10 & 27 & 20 & 9 & 81 \\
\hline mean mean & & 1 & 8 & 1 & 7 & 5 & 22 \\
\hline dip strig & & 5 & 8 & 1 & 4 & 4 & 22 \\
\hline ag ag & & 8 & 1 & 8 & 7 & 1 & 25 \\
\hline mont cav & 1 & 8 & 11 & 10 & 7 & 8 & 45 \\
\hline dip laby & 1 & 2 & 1 & 3 & & & 7 \\
\hline eusmilia & & & & 4 & 1 & & 5 \\
\hline manicina & & & & & & 3 & 3 \\
\hline muss ang & & & 1 & & & & 1 \\
\hline mycetophyllia & 1 & 2 & 7 & 14 & 12 & & 36 \\
\hline col natans & & 1 & & 1 & 6 & 4 & 12 \\
\hline Total & 44 & 53 & 69 & 111 & 107 & 67 & 451 \\
\hline
\end{tabular}

Legend. Coral species: ss, Sidastrea siderea (Ellis, 1786); pa, Porites astreoides (Lamarck, 1816); meanmean, Meandrina meandrites (Linnaeus, 1758); Dip strig, Diploria strigosa (Dana, 1848); agag, Agaricia agaricites (Linnaeus, 1758); mont cav, Montastrea cavernosa (Linnaeus, 1758); dip laby, Diploria labyrinthiformis (Linnaeus, 1758); eusmilia, Eusmilia fastigiata (Pallas, 1766); col natans, Colpophyllia natans (Houttuyn, 1772); manicina, Manicina areolata (Linnaeus, 1758); muss ang, Mussa angulosa (Pallas, 1766); mycetophyllia, Mycetophyllia lamarckiana (Milne Edwards 1848). GPS coordinates of all sites are given in the text. Gaps in the tables indicate 0. 
triplicate, at each site, using photographic image analysis verified by the chain method, as described previously for Discovery Bay sites [25].

\section{Results}

The reefs fringing the cays around Port Royal in Jamaica did not exhibit extensive three-dimensional complexity; this is exemplified by their rugosities: Rackhams cay, $1.42 \pm 0.15$; Edina wreck, $1.37 \pm 0.17$; Drunkenman's cay $1.41 \pm 0.16$; SE Barrier cay, $1.39 \pm 0.15$; Maiden cay, $1.1 \pm 0.1$; Lime cay, $1.16 \pm 0.12$; and Gun cay, $1.17 \pm$ 0.2 .

Despite their low three-dimensional complexity, there was a high proportion of small size classes of nonbranching corals that included new recruits and juveniles on these reefs. This is illustrated for both 2010 and 2012 in Figures 1(a) and (b) for Sidastrea siderea and in Figures 1(c) and (d) for Porites astreoides. These patterns are typical of other species of corals, where the numbers of corals are smaller. Skewness values for both species were positive (for example 1.36 for Sidastrea siderea at the Edina site in 2010, and 0.85 for Porites astreoides at Drunkenman's Cay in 2012), implying more small colonies than large colonies.

There was also a high proportion of small size classes of non-branching corals on the fringing reefs around Discovery Bay on the Jamaican north coast in 2012. This is illustrated for Sidastrea siderea and Porites astreoides in Figures 2(a) and (b). Once again, this pattern was typical of other coral species. Skewness values for both species were positive, with Dairy Bull having the highest values (for example 1.64 for Sidastrea siderea and 1.12 for Porites astreoides in 2012 at Dairy Bull), implying more small colonies than large colonies.

Coral growth rates are part of a demographic approach to monitoring coral reef health in times of climate change, and Figure 3 presents linear extension rates $\left(\mathrm{mm} \cdot \mathrm{yr}^{-1}\right)$ of Acropora palmata branching corals $(\mathrm{n}=4)$ at Dairy Bull,

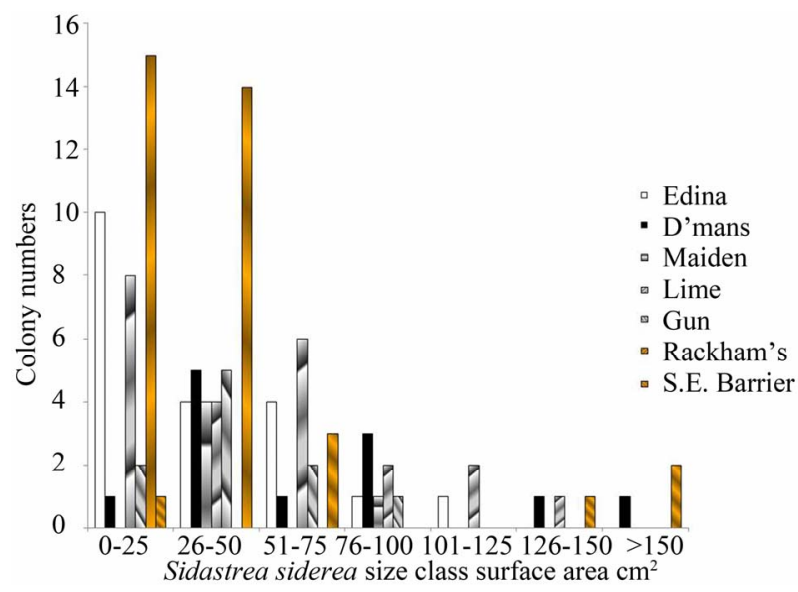

(a)

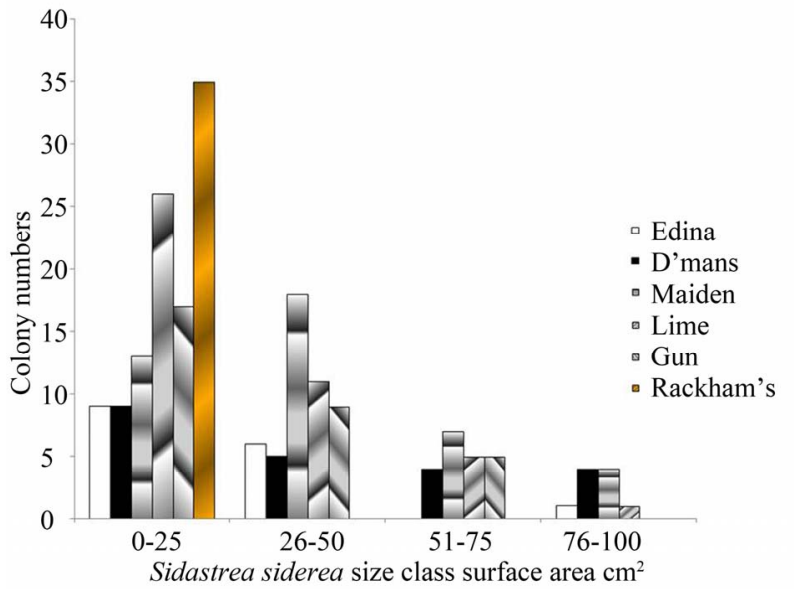

(b)

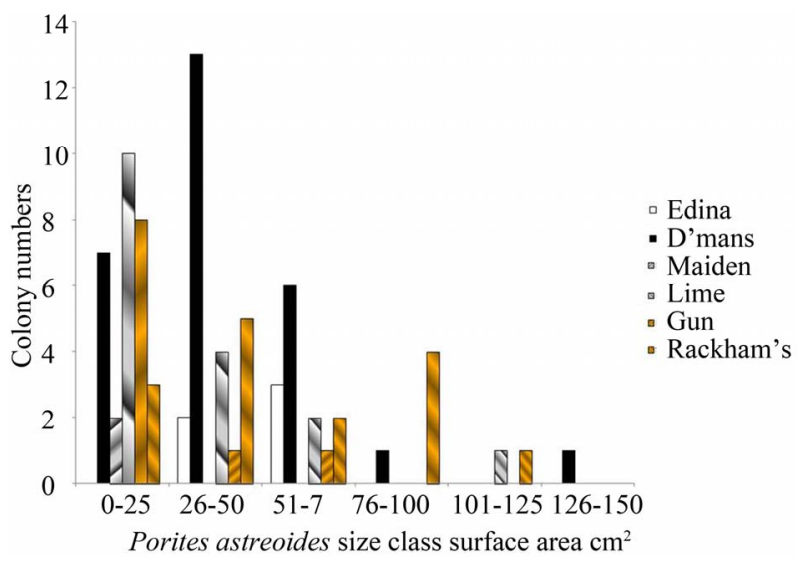

(c)

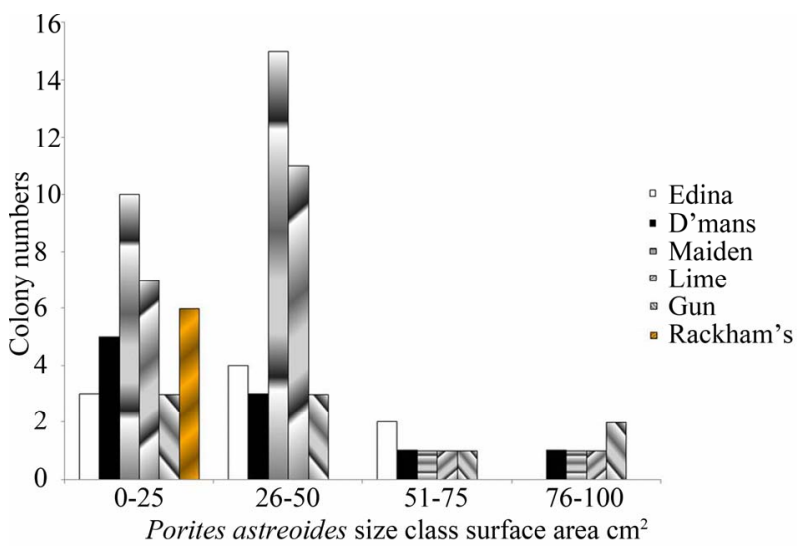

(d)

Figure 1. Size classes of non-branching corals on the fringing reefs on the Port Royal Cays. (a) Sidastrea siderea in 2010; (b) Sidastrea siderea in 2012; (c) Porites astreoides in 2010; (d) Porites astreoides in 2012.

Rio Bueno, and Pear Tree Bottom on the north coast of Jamaica from 2005-2008, and from 2009-2012. Growth rates are similar to those reported previously [21]. There were no significant differences between the sites, or across the time periods of the study. Where growth rates 


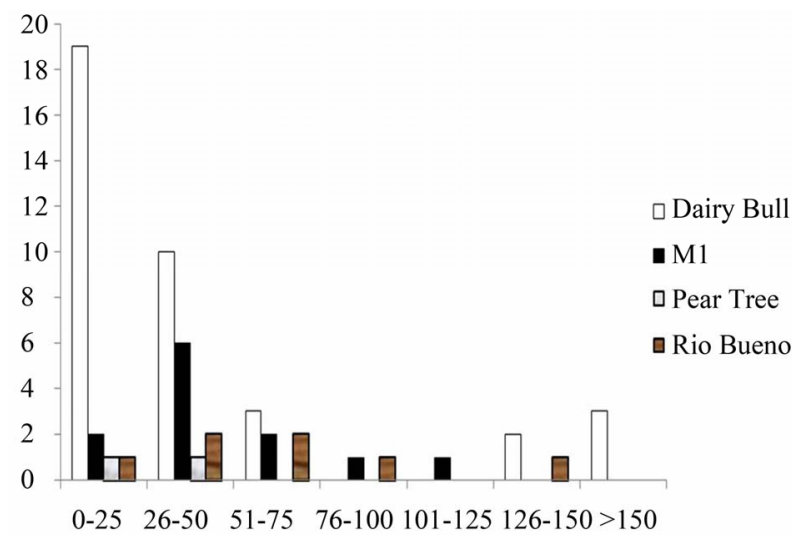

(a)

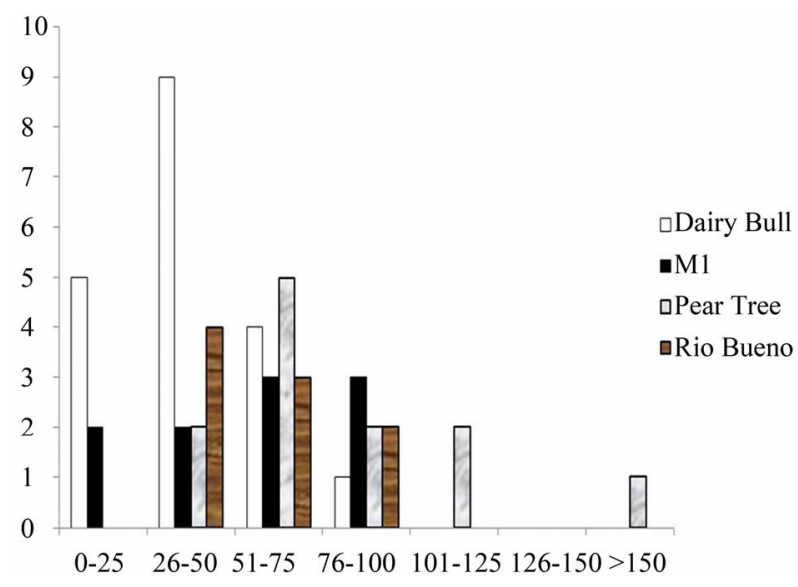

(b)

Figure 2. Size classes of non-branching corals on the fringing reefs near Discovery Bay, Jamaica. (a) Sidastrea siderea in 2012; (b) Porites astreoides in 2012.

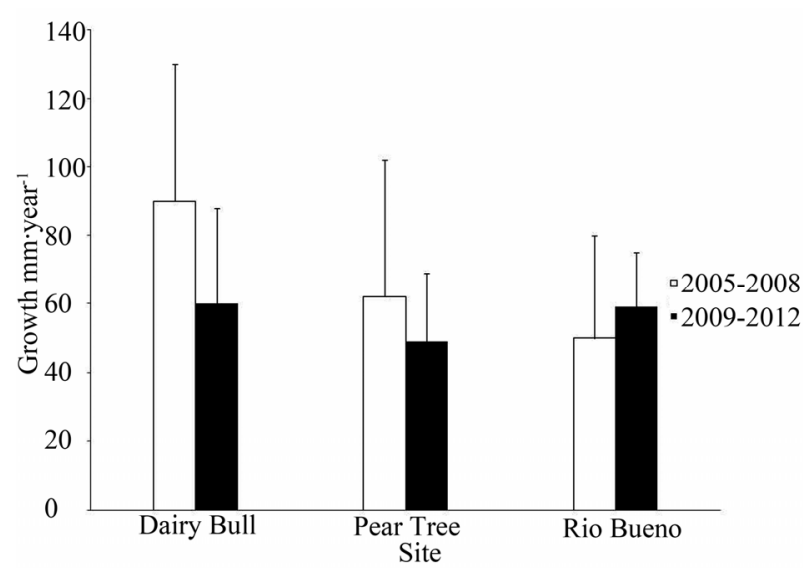

Figure 3. Linear extension rates of Acropora palmata at sites near Discovery Bay, Jamaica, from 2005-2008 and 20092012. Error bars represent standard errors of the data $(n=$ 4).

were higher, they tended to be higher at Dairy Bull reef. With the increase of Diadema antillarum at Rio Bueno in recent years, clearing the macroalgae, many healthy $A$. palmata colonies have appeared at the Rio Bueno site from 2006.

\section{Discussion}

Mesoscale rugosity (larger scale) has been found important for predicting intra-habitat variation in coral reef fish assemblages, and explicitly in predicting the impacts of coral mortality on ecosystem process and services. This particularly relates to large, tall $(>50 \mathrm{~cm})$ corals [26]. Loss of architectural complexity in Caribbean reefs due to climate change appears to be linked to physical impacts, such as hurricanes and bio-erosion [3].

The range of small-scale rugosities at the Port Royal cay sites studied was lower than that at the Discovery Bay sites [25]; for example Rio Bueno was $1.05 \pm 0.15$ and Dairy Bull the most rugose at $2.3 \pm 0.16$. Diary Bull reef has for several years been the fringing reef with the most coral cover, with a benthic community similar to that of the 1970s [21], and it was the subject of the study which suggested a rapid phase-shift reversal [27].

In addition to climate change, Jamaican reefs are subject to a number of acute and chronic stressors, the last including overfishing and continuing coastal development, including the much-publicised development on land adjacent to Pear Tree Bottom reef and the resurfaceing of the North Jamaican coastal highway [28]. Faster rates of macroalgal growth, higher rates of algal recruitment iron enrichment from Aeolian dust, lack of acroporid corals, lower herbivore biomass and missing groups of herbivores all predispose the Caribbean to low resilience, relative to the Indo-Pacific region [29].

The Kingston harbour area has been impacted for many decades $[16,19]$ and there have been efforts at mitigation, particularly in association with the ship channel [30]. In addition, some coral communities may adapt to chronic stressors, for example sedimentation, over long periods of time [31].

After the 2005 bleaching event there was a major loss of live coral cover [32,33], and it is encouraging that the population size studies show that there are numbers of both small and large colonies at both Discovery Bay and Port Royal sites. Also, the linear extension rates of $A$. palmata branching corals at Dairy Bull, Rio Bueno, and Pear Tree Bottom on the north coast of Jamaica were maintained from 2005-2012.

The influence of $M$. annularis colonies on the reef, acting as structural refugia [27], with maintenance of the biological legacies, may have facilitated this recovery. In addition, there have been no major hurricanes or bleaching events due to climate change since 2005 until this study which have impacted Jamaican fringing reefs.

Unlike other areas in the Caribbean, Jamaica has few Marine Protected Areas (MPAs) or Marine Reserves. 
MPAs have been suggested as means for enhancing local resilience and population growth of marine species [e.g. 34,35]. However, some studies have highlighted continued climatic and other impacts in regions of MPAs [36-38].

Belize has the highest annual capture production-the annual volume of aquatic species caught by country for all commercial, industrial, recreational and subsistence purposes, in 2010, for countries in the Caribbean for which data is available [39]. The Belize continental shelf also includes the MesoAmerican Barrier reef; this World Heritage Site has levered the adoption of Marine Protected Areas (MPAs) for Belize. In 2010, Belize had $11.86 \%$ of its territorial waters as MPAs. This compares with Jamaica, 4.2\%; Trinidad and Tobago, 2.8\%; Barbados, 0.1\%; St. Kitts and Nevis, 0.5\%; St. Lucia, 0.1\%; St. Vincent and the Grenadines, $0.6 \%$. Figure 4 shows the relationship between percentage of a country's territorial waters as MPAs with volume of catch $\left(\mathrm{r}^{2}=0.88\right)$; there is a similar correlation $\left(r^{2}=0.66\right)$ with fisheries as a percentage of GDP [40] for the country concerned. Catch is a function of effort, and capture production may reflect this in addition to the influence of MPAs.

Recognition of the importance of fisheries in a country's GDP may be a factor in empowering conservation policy as well as local stakeholder action to conserve coral reefs. Having a large percentage of its territorial waters as MPAs, and in a coordinated network of MPAs, may reflect in the value of a country's fishing industry.

The 2012 IUCN report [41] on Caribbean coral reefs points to the decline of Caribbean reefs from c. $50 \%$ cover in the 1970 to just $8 \%$ today. They call for strictly enforced local action to improve the health of corals, including limiting fishing through catch quotas, an extension of MPAs, a halt to nutrient run-off from the land, and a reduction on the global resilience on fossil fuels.

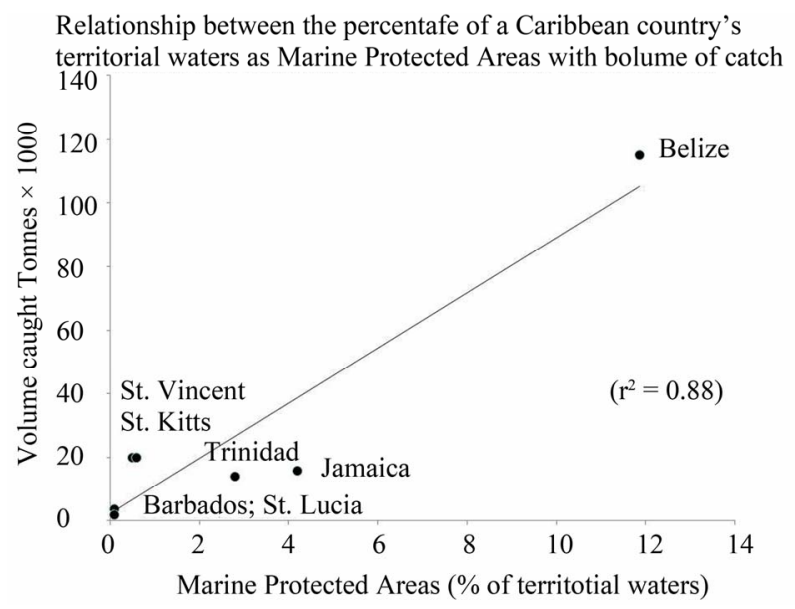

Figure 4. Relationship between the percentage of a country's territorial waters as Marine Protected Areas (MPAs) with volume of catch $\left(r^{2}=0.88\right)$.
Through the IUCN-coordinated Global Coral Reef Monitoring Network (e.g. [42]) there are moves to strengthen the data available at a worldwide level.

Protection using fully protected MPAs is one of the few management tools that governments and local communities can use to combat large scale environmental impacts. In Bajja California, such an MPA provided protection to marine populations both within and outside the protected area [43]. The degree of protection is critical [44]. At Glover's Reef Marine Reserve, a no-take policy has not resulted in increases in grazing fish abundance, although commercially important fish, such as black grouper (Mycteroperca bonaci) and lane snapper (Lutjanus synagris) and invertebrates have increased [45]. This could be for many reasons, not least if they are poorly managed and maintained over long periods, particularly when there are stressful environmental events such as hurricanes of high sea surface temperatures (SSTs).

In an environment where carbon dioxide concentrations predicted to occur at the end of this century would significantly reduce coral settlement and crustose coralline algae cover, and would so reduce successful coral recruitment and larval settlement [46,47], establishing and maintaining fully-protected marine parks in Jamaica and elsewhere in the Caribbean is one tool to help the future of the fishing industry in developing countries.

Where protection in MPAs was not found to reduce the effect of warm temperature anomalies on coral cover declines [48], then shortcomings in MPA design, including size and placement, may have contributed to the lack of an MPA effect. It may be that the benefits from single MPAs may not be great enough to offset the magnitude of losses from acute thermal stress events. Although MPAs are important conservation tools, their limitations in mitigating coral loss from acute thermal stress events suggest that they need to be complemented with policies aimed at reducing the activities responsible for climate change. One way forward is to have networks of MPAs [49], and they could be more effective in conjunction with other management strategies, such as fisheries regulations and reductions of nutrients and other forms of land-based pollution. Developing MPAs as part of an overall climate change policy for a country [50] may be the best way of integrating climate change into MPA planning, management, and evaluation.

\section{Acknowledgements}

I thank Mr. Peter Gayle and the staff of the Discovery Bay Marine Laboratory Jamaica, Mr. Hugh Small and colleagues at Port Royal Marine Station, Jamaica for their invaluable help and assistance. I also thank Ms. Marcia Creary and staff of the University of the West 
Indies, Mona campus, for their logistical help, and Margaret O'Rorke for invaluable conversations.

\section{REFERENCES}

[1] T. A. Gardner, I. M. Côté, J. A. Gill, A. Grant and A.R. Watkinson, "Long-Term Region-Wide Declines in Caribbean Corals," Science, Vol. 301, No. 5635, 2003, pp. 958-960. doi:10.1126/science. 1086050

[2] C. M. Eakin, J. A. Morgan, S. F. Heron, T. B. Smith, G. Liu, L. Alvarez-Filip, B. Baca, E. Bartels, C. Bastidas, C. Bouchon, M. Brandt, A. Bruckner, L. Bunkley-Williams, A. Cameron, B. D. Causey, M. Chiappone, T. R. L. Christensen, M. J. C. Crabbe, O. Day, E. de la Guardia, G. Díaz-Pulido, D. DiResta, D. L. Gil-Agudelo, D. Gilliam, R. Ginsburg, S. Gore, H. M. Guzman, J. C. Hendee, E. A. Hernández-Delgado, E. Husain, C. F. G. Jeffrey, R. J. Jones, E. Jordán-Dahlgren, L. Kaufman, D. I. Kline, P. Kramer, J. C. Lang, D. Lirman, J. Mallela, C. Manfrino, J.-P. Maréchal, K. Marks, J. Mihaly, W. J. Miller, E. M. Mueller, E. Muller, C. A. Orozco Toro, H. A. Oxenford, D. Ponce-Taylor, N. Quinn, K. B. Ritchie, S. Rodríguez, A. Rodríguez Ramírez, S. Romano, J. F. Samhouri, J. A. Sánchez, G. P. Schmahl, B. Shank, W. J. Skirving, S. C. C. Steiner, E. Villamizar, S. M. Walsh, C. Walter, E. Weil, E. H. Williams, Woody K. Roberson and Y. Yusuf, "Caribbean Corals in Crisis: Record Thermal Stress, Bleaching, and Mortality in 2005," PLOS ONE, Vol. 5, No. 11, 2010, Article ID: e13969.

doi:10.1371/journal.pone.0013969

[3] L. Alvarez-Filip, J. A. Gill, N. K. Dulvy, A. L. Perry, A. R. Watkinson and I. M. Coté, "Drivers of Region-Wide Declines in Architectural Complexity on Caribbean Reefs," Coral Reefs, Vol. 30, No. 4, 2011, pp. 1051-1060. doi:10.1007/s00338-011-0795-6

[4] R. Rodolfo-Metalpa, F. Houlbréque, E. Tambutté, F. Biosson, C. Baggini, F. P. Patti, R. Jefree, M. Fine, A. Foggo, J-P. Gattuso and J. M. Hall-Spencer, "Coral and Mollusc Resistance to Ocean Acidification Adversely Affected by Warming," Nature Climate Change, Vol. 1, 2011, pp. 308-312. doi:10.1038/nclimate1200

[5] J. D. Woodley, E. A. Chornesky, P. A. Clifford, J. B. C. Jackson, L. S. Kaufman, N. Knowlton, J. C. Lang, M. P. Pearson, J. W. Porter, M. C. Rooney, K. W. Rylaarsdam, V. J. Tunnicliffe, C. M. Wahle, J. L. Wulff, A. S. G. Curtis, M. D. Dallmeyer, B. P. Jupp, M. A. R. Koehl, J. Neigel and E. M. Sides, "Hurricane Allen's Impact on Jamaican Coral Reefs," Science, Vol. 214, No. 4522, 1981, pp. 749-755.

[6] M. J. C. Crabbe, J. M. Mendes and G. F. Warner, Lack of Recruitment of Non-Branching Corals in Discovery Bay Is Linked to Severe Storms," Bulletin of Marine Science, Vol. 70, 2002, pp. 939-945.

[7] J. Mallela and M. J. C. Crabbe, "Hurricanes and Coral Bleaching Linked to Changes in Coral Recruitment in Tobago," Marine Environmental Research, Vol. 68, No. 4, 2009, pp. 158-162. doi:10.1016/j.marenvres.2009.06.001

[8] J. B. C. Jackson, "Reefs since Columbus," Proceedings of the 8th International Coral Reef Symposium, Vol. 1, 1997, pp. 97-106.

[9] J. P. Hawkins and C. M. Roberts, "Effects of Artisanal Fishing on Caribbean Coral Reefs," Conservation Biology, Vol. 18, No. 1, Conservation Biology, Vol. 18, 2004, pp. 215-226. doi:10.1111/j.1523-1739.2004.00328.x

[10] T. P. Hughes, "Catastrophes, Phase Shifts and LargeScale Degradation of a Caribbean Coral Reef," Science, Vol. 265, No. 5178, 1994, pp. 1547-1551. doi:10.1126/science.265.5178.1547

[11] R. B. Aronson and W. F. Precht, "Evolutionary Paleoecology of Caribbean Coral Reefs," In: W. D. Allmon and D. J. Bottjer, Eds., Evolutionary Paleoecology: The Ecological Context of Macroevolutionary Change, Columbia University Press, New York, 2001, pp. 171-233.

[12] A. M. Greenaway and D.-A. Gordon-Smith, "The Effects of Rainfall on the Distribution of Inorganic Nitrogen and Phosphorus in Discovery Bay, Jamaica," Limnology and Oceanography, Vol. 51, 2006, pp. 2206-2220.

[13] E. H. I. Meesters, M. Hilterman, E. Kardinaal, M. Keetman, M. de Vries and R. P. M. Bak, "Colony Size-Frequency Distributions of Scleractinian Coral Populations: Spatial and Interspecific Variation," Marine Ecology Progress Series, Vol. 209, 2001, pp. 43-54.

[14] L. D. Smith, M. Devlin, D. Haynes and J. Gilmour, "A Demographic Approach to Monitoring the Health of Coral Reefs," Marine Pollution Bulletin, Vol. 51, No. 1-4, 2005, pp. 399-407.

doi:10.1016/j.marpolbul.2004.11.021

[15] Monitoring Report, "Final Monitoring Report, Dredging and Reclamation Programme in Kingston Harbour," National Environmental Protection Agency, Jamaica, 29 November 2002.

http://www.nrca.org/publications/coastal/monitoring_rep/ reports/MONITORING_REPORTFnl.pdf

[16] B. A. Wade, L. Antonio and R. Mahon, "Increasing Organic Pollution in Kingston Harbour, Jamaica," Marine Pollution Bulletin, Vol. 3, No. 7, 1972, pp. 106-111. doi:10.1016/0025-326X(72)90251-2

[17] A. Mansingh and A. Wilson, "Insecticide Contamination of Jamaican Environment III. Baseline Studies on the Status of Insecticidal Pollution of Kingston Harbour," Marine Pollution Bulletin, Vol. 30, No. 10, 1995, pp. 640-645. doi:10.1016/0025-326X(95)00038-O

[18] J. E. Andrews, A. M. Greenaway, G. R. Bigg, D. F. Webber, P. F. Dennis and G. A. Guthrie, "Pollution History of a Tropical Estuary Revealed by Combined Hydrodynamic Modelling and Sediment Geochemistry," Journal of Marine Systems, Vol. 18, No. 4, 1999, pp. 333-343. doi:10.1016/S0924-7963(98)00019-0

[19] A. M. Maxam and D. F. Webber, "Using the Distribution of Physicochemical Variables to Portray Reefal Bay Waters," Journal of Coastal Research, Vol. 25, No. 6, 2009, pp. 1210-1221. doi:10.2112/08-1046.1

[20] M. J. C. Crabbe, "The Influence of Extreme Climate Events on Models of Coral Colony Recruitment and Survival in the Caribbean," American Journal of Climate Change, Vol. 1, 2012, pp. 33-40. 
doi:10.4236/ajcc.2012.11003

[21] M. Huston, "Variation of Coral Growth Rates with Depth at Discovery Bay, Jamaica," Coral Reefs, Vol. 4, No. 1, 1985, pp. 19-25. doi:10.1007/BF00302200

[22] T. P. Hughes and J. B. C. Jackson, "Do Corals Lie about Their Age? Some Demographic Consequences of Partial Mortality, Fission, and Fusion," Science, Vol. 209, No. 4457, 1980, pp. 713-715. doi:10.1126/science.209.4457.713

[23] N. L. Foster, I. B. Baums and P. J. Mumby, "Sexual vs Asexual Reproduction in an Ecosystem Engineer: The Massive Coral Montastrea annularis," Journal of Animal Ecology, Vol. 76, No. 2, 2007, pp. 384-391. doi:10.1111/j.1365-2656.2006.01207.x

[24] Z. H. Zar, "Biostatistical Analysis," 4th Edition, Prentice-Hall, Upper Saddle River, 1999, p. 663.

[25] M. J. C. Crabbe, "Topography and Spatial Arrangement of Reef-Building Corals on the Fringing Reefs of North Jamaica May Influence Their Response to Disturbance from Bleaching," Marine Environmental Research, Vol. 69, No. 3, 2010, pp. 158-162. doi:10.1016/j.marenvres.2009.09.007

[26] A. R. Harborne, P. J. Mumby and R. Ferrari, "The Effectiveness of Different Meso-Scale Rugosity Metrics for Predicting Intra-Habitat Variation in Coral Reef Assemblages," Environmental Biology of Fishes Vol. 94, 2012, pp. 431-442. doi:10.1007/s10641-011-9956-2

[27] J. A. Idjadi, S. C. Lee, J. F. Bruno, W. F. Precht, L. Allen-Requa and P. J. Edmunds, "Rapid Phase-Shift Reversal on a Jamaican Coral Reef," Coral Reefs, Vol. 25, 2006, pp. 209-211.

[28] I. Westfield, S. Dworkin, R. Bonem and E. Lane, "Identification of Sediment Sources Using Geochemical Fingerprinting at Pear Tree Bottom Reef, Runaway Bay, Jamaica," Abstracts of the 11th International Coral Reef Society, 2008, p. 137.

[29] G. Roff and P. J. Mumby, "Global Disparity in the Resilience of Coral Reefs," Trends in Ecology \& Evolution, Vol. 27, No. 7, 2012, pp. 404-413. doi:10.1016/j.tree.2012.04.007

[30] P. M. H. Gayle, P. Wilson-Kelly and S. Green, V. S. Flood, J. M. Pitt and S. R. Smith, "Transplantation of Benthic Species to Mitigate Impacts of Coastal Developments in Jamaica," Revista de Biologia Tropical, Vol. 53,2005, pp. 105-115.

[31] V. S. Flood, J. M. Pitt and S. R. Smith, "Historical and Ecological Analysis of Coral Communities in Castle Harbour (Bermuda) after More than a Century of Environmental Perturbation," Marine Pollution Bulletin, Vol. 51, No. 5-7, 2005, pp. 545-557. doi:10.1016/j.marpolbul.2005.07.010

[32] N. J. Quinn and B. L. Kojis, "The Recent Collapse of a Rapid Phase-Shift Reversal on a Jamaican North Coast Reef after the 2005 Bleaching Event," International Journal of Tropical Biology, Vol. 56, Suppl. 1, 2008, pp. 149-159. doi:10.1016/j.marenvres.2009.01.003

[33] M. J. C. Crabbe, "Scleractinian Coral Population Size Structures and Growth Rates Indicate Coral Resilience on the Fringing Reefs of North Jamaica," Marine Environmental Research, Vol. 67, No. 4-5, 2009, pp. 189-198.

[34] F. R. Gell and C. M. Roberts, "Benefits beyond Boundaries: The Fishery Effects of Marine Reserves," Trends in Ecology and Evolution, Vol. 18, 2003, pp. 448-455. doi:10.1016/S0169-5347(03)00189-7

[35] S. Macia, M. P. Robinson and A. Nalevanko, "Experimental Dispersal of Recovering Diadema antillarum increases Grazing Intensity and Reduces Macroalgal Abundance on a Coral Reef," Marine Ecology-Progress Series, Vol. 348, 2007, pp. 173-182. doi:10.3354/meps06962

[36] I. M. Côté and E. S. Darling, "Rethinking Ecosystem Resilience in the Face of Climate Change," PLoS Biology, Vol. 8, No. 7, 2010, Article ID: e1000438. doi:10.1371/journal.pbio.1000438

[37] T. P. Hughes, N. A. J. Graham, J. B. C. Jackson, P. J. Mumby and R. S. Stenek, "Rising to the Challenge of Sustaining Coral Reef Resilience," Trends in Ecology and Evolution, Vol. 25, No. 11, 2010, pp. 633-642. doi:10.1016/i.tree.2010.07.011

[38] C. Mora and P. F. Sale, "Ongoing Global Biodiversity Loss and the Need to Move beyond Protected Areas: A Review of the Technical and Practical Shortcomings of Protected Areas on Land and Sea," Marine Ecology Progress Series, Vol. 434, 2011, pp. 251-266. doi:10.3354/meps09214

[39] FAO, "The State of World Fisheries and Aquaculture," FAO, Rome, 2012. http://www.fao.org/corp/statistics/en/

[40] World Bank, "Global Financial Development Report 2013: Rethinking the Role of the State in Finance," World Bank, New York, 2012. http://data.worldbank.org/

[41] IUCN (International Union for the Conservation of Nature), "2012 Report on Caribbean Coral Reefs," IUCN.

[42] L. Jones, P. M. Alcolado, Y. Cala, D. Cobián, V. Coelho, A. Hernández, R. Jones, J. Mallela and C. Manfrino, "The Effects of Coral Bleaching in the Northern Caribbean and Western Atlantic," In: C. Wilkinson and D. Souter, Eds., Status of Caribbean Coral Reefs after Bleaching and Hurricanes in 2005, Global Coral Reef Monitoring Network, and Reef and Rainforest Research Centre, Townsville, 2008, pp. 73-83.

[43] F. Micheli, A. Saenz-Arroyo, A. Greenley, L. Vazquez, J. A. E. Montes, M. Rossetto and G. A. Leo, "Evidence that Marine Reserves Enhance Resilience to Climatic Impacts," PLoS ONE, Vol. 7, No. 7, 2012, Article ID: e-40832 doi:10.1371/journal.pone.0040832

[44] Z. Sary, H. A. Oxenford and J. D. Woodley, "Effects of an Increase in Trap Mesh Size on an Over-Exploited Coral Reef Fishery at Discovery Bay, Jamaica," Marine Ecology Progress Series, Vol. 154, 1997, pp. 107-120. doi: $10.3354 /$ meps 154107

[45] B. E. Huntington, M. Karnauskas and D. Lirman, "Corals Fail to Recover at a Caribbean Marine Reserve Despite Ten Years of Reserve Designation," Coral Reefs, Vol. 30, No. 4, 2012, pp. 1077-1085. doi:10.1007/s00338-011-0809-4

[46] C. Doropoulos, S. Ward, G. Diaz-Pulido, O. Hoegh- 
Guldberg and P. J. Mumby, "Ocean Acidification Reduces Coral Recruitment by Disrupting Intimate Larval-Algal Settlement Interactions," Ecology Letters, Vol. 15, No. 4, 2012, pp. 338-346.

doi:10.1111/j.1461-0248.2012.01743.x

[47] K. Frieler, M. Meinhausen, A. Golly, M. Mengel, K. Lebek, S. D. Donner and O. Hoegh-Guldberg, "Limiting Global Warming to $2^{\circ} \mathrm{C}$ Is Unlikely to Save Most Coral Reefs," Nature Climate Change, Vol. 3, 2013, pp. 165170. doi:10.1038/nclimate1674

[48] E. R. Selig, K. S. Casey and J. F. Bruno, "Temperature-Driven Coral Decline: The Role of Marine Protected Areas," Global Change Biology, Vol. 18, No. 5, 2012, pp.
1561-1570. doi:10.1111/j.1365-2486.2012.02658.x

[49] B. D. Keller, D. F. Gleason, E. McLeod, C. M. Woodley, S. Airame, B. D. Causey, A. M. Friedlander, R. GroberDunsmore, J. E. Johnson, S. L. Miller and R. S. Steneck, "Climate Change, Coral Reef Ecosystems, and Management Options for Marine Protected Areas," Environmental Management, Vol. 44, No. 6, 2009, pp. 1069-1088. doi:10.1007/s00267-009-9346-0

[50] P. Söderholm, "Modeling the Economic Costs of Climate Policy: An Overview," American Journal of Climate Change, Vol. 1 No. 1, 2012, pp. 14-32. doi:10.4236/ajcc.2012.11002 